\title{
Country-specific emission factors for methane emission from enteric fermentation: a case study from a non-annex 1 country
}

\author{
E. Lokupitiya* \\ Department of Zoology and Environment Sciences, Faculty of Science, University of Colombo, Colombo 03.
}

Revised: 15 July 2015; Accepted: 28 October 2015

\begin{abstract}
Methane emission from enteric fermentation is a subcategory considered under the Agriculture sector greenhouse gas emissions under the United Nations Framework Convention on Climate Change (UNFCCC). So far, most non-annex 1 member countries have used the default IPCC 1996 revised guidelines in estimating such emissions. The latest IPCC 2006 revised guidelines for national greenhouse gas inventories provide better guidelines for developing country-specific emission factors. Countryspecific methane emission factors were developed for estimating methane emission from enteric fermentation in livestock in Sri Lanka, using a Tier 2 approach with energy calculations (IPCC, 2006) based on country-specific activity data. Each animal category was further subdivided for the analyses, and emission estimates incorporated population characteristics in the different agro-climatic zones of the country. Separate emission factors were calculated for sub categories within the local (indigenous) and improved (Indian and European) breeds. The population-weighted methane emission factor (50 kg head $\mathrm{d}^{-1} \mathrm{yr}^{-1}$ ) estimated for dairy cows (i.e. lactating females) was lower than the IPCC default value. The methane emission factors calculated for other cattle categories ranged between $11-58 \mathrm{~kg} \mathrm{head}^{-1} \mathrm{yr}^{-1}$. However the population-weighted emission factor $(32 \mathrm{~kg}$ head $^{-1} \mathrm{yr}^{-1}$ ) was slightly higher than the IPCC default value $\left(27 \mathrm{~kg} \mathrm{head}^{-1} \mathrm{yr}^{-1}\right)$, as the proportion of the calves in the other cattle population was relatively lower ( $\sim 47$ percent) than what the IPCC default emission factor has considered. Overall, the population-weighted emission factors for buffaloes (49 kg head $\left.{ }^{-1} \mathrm{yr}^{-1}\right)$ and sheep $\left(3 \mathrm{~kg} \mathrm{head}^{-1} \mathrm{yr}^{-1}\right)$ were lower than the IPCC default values.
\end{abstract}

Keywords: Climate change, enteric fermentation, greenhouse gas inventory, IPCC Tier 2 methodology, livestock, methane emissions.

\section{INTRODUCTION}

Anthropogenic climate change and increased levels of greenhouse gases (GHG) in the atmosphere led to the adoption of the United Nations Framework Convention on Climate Change (UNFCCC) at the Rio Earth Summit held in 1992. Agriculture has been identified as one of the key source/sink categories under the UNFCCC, and methane $\left(\mathrm{CH}_{4}\right)$ emissions from enteric fermentation is a sub category under Agriculture. Under the UNFCCC, the member countries are expected to submit a national greenhouse gas inventory. Annex 1 (developed) countries are required to submit an annual national greenhouse gas inventory. Although an annual submission is not required from the non-annex 1 (developing) countries, they are also expected to submit periodic greenhouse gas inventories and are encouraged to develop their own methodologies and emission factors, wherever applicable.

So far the developing countries have been mostly using the Revised 1996 Intergovernmental Panel on Climate Change (IPCC) Guidelines for National Greenhouse Gas Inventories, following from the decision 17/COP 8 (UNFCCC, 2003). In addition to the default IPCC 1996 methodology (IPCC 1997a;b;c), some developing countries have also been using the IPCC Good Practice Guidance (IPCC 2000; 2003). The latest IPCC 2006 guidelines for national greenhouse gas inventories are more elaborate, and provide guidelines for developing country specific emission factors under certain GHG source/sink sub categories.

The main objective of this study is to develop countryspecific methane emission factors for enteric fermentation in major livestock categories in Sri Lanka, following the Tier 2 methodology under the IPCC 2006 guidelines. 
Table 1: Livestock population in different agro ecological zones of Sri Lanka in 2002 and 2014

\begin{tabular}{lcccc}
\hline Category & Dry Zone & Wet Zone & Intermediate Zone & Total \\
\hline 2002 & & & & \\
Cattle & 591,997 & 217,407 & 277,185 & $1,086,589$ \\
Buffaloes & 132,121 & 65,369 & 89,936 & 287,426 \\
Sheep and goat & 182,268 & 38,076 & 44,240 & 264,584 \\
Swine & 26,857 & 15,725 & 15,770 & 58,352 \\
Poultry* & $4,331,663$ & $4,458,197$ & $4,386,181$ & $13,176,041$ \\
Total & $5,264,906$ & $4,786,774$ & $4,813,312$ & $14,872,992$ \\
& & & \\
& & & & \\
Cattle & 658,200 & 236,150 & 210,430 & $1,104,780$ \\
Buffaloes & 177,280 & 83,690 & 59,720 & 320,690 \\
Sheep and goat & 186,480 & 85,580 & 38,030 & 310,090 \\
Swine & 52,700 & 37,670 & 14,840 & 105,210 \\
Poultry* & $4,074,685$ & $5,422,550$ & $7,144,875$ & $16,642,110$ \\
Total & $5,149,345$ & $5,865,640$ & $7,467,895$ & $18,482,880$ \\
\hline * Chickens, ducks, and turkey. & \multicolumn{4}{l}{} \\
Source: Department of Census and Statistics (http://www.statistics.gov.lk/agriculture/) &
\end{tabular}

Agriculture is a major economic sector in the developing countries in South Asia. In Sri Lanka, the overall agriculture sector and livestock sub sector contribute $11.1 \%$ and $1.0 \%$, respectively to the gross domestic product (GDP) (Central Bank of Sri Lanka, 2013). Although the livestock sector has been used for the dairy requirement of the country, the major part of the requirement is still met by dairy imports (Abeygunawardena et al., 1997; Bandara et al., 2011). Sri Lanka, as a tropical island in the Indian Ocean, has been experiencing various impacts of climate change. The country has been a member of the United Nations Framework Convention on Climate Change (UNFCCC) since its ratification in 1993. So far, Sri Lanka has produced two national communications including sector wise greenhouse gas inventories. The current study analyses the country-specific activity data and other information to derive country-specific methane emission factors for enteric fermentation using the IPCC Tier 2 methodology (IPCC, 2006), to supplement and compare with the existing default values given by the IPCC (2006) for livestock in the Indian subcontinent.

\section{Methane emission from enteric fermentation}

Livestock populations with ruminants emit methane due to the anaerobic digestive process in the forestomachs (i.e. fermentation). Up to $12 \%$ of dietary energy in ruminant livestock can be lost in the form of methane (Blaxter, 1967), and such methane production from ruminants could range from 250 to 500 liters a day (Johnson \& Johnson, 1995). Enteric fermentation contributes to $17 \%$ of the global methane emissions (Knapp et al., 2014). The amount of $\mathrm{CH}_{4}$ emitted depends on the body size, metabolism, activity level of the animals, and their feed quality, etc. Low quality forage including grasses causes higher amounts of $\mathrm{CH}_{4}$ emission, and most of the indigenous/local cattle and buffaloes in Sri Lanka feed on low quality grasses, straw, and other crop residues (Zemmerlink et al., 1999). Improved (European and Indian) cattle breeds are normally given higher quality, concentrate feed, mostly consisting of coconut cake and rice bran (Buvendran, 1977) and they have higher digestive efficiencies with reduced $\mathrm{CH}_{4}$ emissions.

In Sri Lanka, cattle and buffaloes are the major livestock groups, while goats, swine, and sheep remain as the minor groups (Table 1). Cattle, buffaloes, and sheep are the ruminant categories, and country-specific emission factors for methane emissions from enteric fermentation were derived considering the sub categories of these animals.

\section{METHODOLOGY}

In deriving the methane emission factors, population characteristics of the different livestock categories were studied using population data from the agriculture census in 2002 (http://www.statistics.gov.lk/agriculture/) (Table 1), which was the last comprehensive census on livestock in Sri Lanka including information on local (i.e. indigenous) and improved breeds.

Out of all cattle breeds, indigenous cattle constituted about $85 \%$ of the population, while improved breeds constituted $15 \%$. Indigenous cattle constituted 93, 86.2, and $76 \%$ of the total population in Dry, Intermediate, 
Table 2: Information relevant to prominent livestock types in Sri Lanka

\begin{tabular}{|c|c|c|c|c|c|c|c|}
\hline \multirow[t]{2}{*}{ Animal breed } & \multicolumn{3}{|c|}{ Weight (kg) } & \multirow{2}{*}{$\begin{array}{l}\text { Weight } \\
\text { gain per } \\
\text { day }(g)\end{array}$} & \multirow{2}{*}{$\begin{array}{c}\text { Milk } \\
\text { production } \\
\text { per lactation } \\
\text { (Litres) }\end{array}$} & \multirow{2}{*}{$\begin{array}{c}\text { Percent } \\
\text { fat in } \\
\text { milk }\end{array}$} & \multirow{2}{*}{$\begin{array}{c}\text { Wool } \\
\text { production } \\
\left(\mathrm{kg} \mathrm{yr}^{-1}\right)\end{array}$} \\
\hline & $\begin{array}{l}\text { Adult } \\
\text { males }\end{array}$ & $\begin{array}{c}\text { Adult } \\
\text { females }\end{array}$ & Calves* & & & & \\
\hline \multicolumn{8}{|l|}{ Cattle } \\
\hline Friesian & $360-410$ & $250-300$ & 32 & 550 & $3000-3500$ & $3.0-3.5$ & -- \\
\hline Ayershire & $320-360$ & $225-270$ & 30 & & $2750-3000$ & 4.0 & -- \\
\hline Jersey & $270-320$ & $180-225$ & 25 & 410 & 2250 & $4.5-5.4$ & -- \\
\hline Australian & $270-320$ & $180-225$ & 27 & & 2000 & $4.5-5.4$ & -- \\
\hline Sahiwal & $225-270$ & $180-200$ & 22 & 375 & 1100 & 4.5 & -- \\
\hline Red Sindhi & $200-225$ & $135-160$ & 20 & & 1000 & $4.5-4.9$ & -- \\
\hline Tharpakar & $225-270$ & $180-200$ & 25 & & 1000 & $4.2-4.7$ & -- \\
\hline Indigenous & $160-200$ & $140-180$ & 18 & 260 & 450 & $4.2-4.7$ & -- \\
\hline \multicolumn{8}{|l|}{ Bufflaloes } \\
\hline Murrah & 600 & 500 & 35 & 600 & -- & 7.6 & -- \\
\hline Nilli Ravi & 600 & 500 & 33 & 550 & -- & 7.8 & -- \\
\hline Indigenous & $200-225$ & $180-200$ & 22 & 375 & 300 & $7.2-7.7$ & -- \\
\hline \multicolumn{8}{|l|}{ Goats } \\
\hline Jamnapari & $35-45$ & $30-32$ & 2.5 & & -- & $5.6-6.0$ & -- \\
\hline Sannan & $34-43$ & $23-34$ & 2.0 & 110 & 375 & 3.6 & -- \\
\hline Indigenous & -- & -- & 1.6 & 90 & & 4.2 & -- \\
\hline \multicolumn{8}{|l|}{ Sheep } \\
\hline South Down & $40-45$ & $30-32$ & -- & & -- & -- & $1.5-2.0$ \\
\hline Red Madras & $30-40$ & $20-30$ & $2-3$ & & & & \\
\hline Jaffna sheep & $15-20$ & 7 & 1.2 & & -- & -- & -- \\
\hline Indigenous & $15-20$ & 7 & 1.2 & & -- & -- & -- \\
\hline \multicolumn{8}{|l|}{ Swine } \\
\hline Landacre & & & 1.4 & 450 & & & \\
\hline Large white & $135-200$ & & 1.2 & 400 & & & \\
\hline Indigenous & & -- & 0.8 & 225 & -- & -- & -- \\
\hline
\end{tabular}

* Weight at birth; -- not relevant or data unavailable. Source: Ministry of Livestock Development, 2008 (unpublished data)

and Wet Zones, respectively. Similarly, indigenous buffaloes accounted for $92.2,92.3$, and $84.7 \%$ of the total buffalo population in the Dry, Intermediate, and Wet Zones, respectively. Improved buffalo population in the country was only about $9 \%$ of the total buffalo population. From 2002 to 2014, the total numbers in different livestock categories have increased with a marked reduction in the numbers of ruminant livestock in the Intermediate Zone.

Some information on the local and improved cattle and other livestock breeds are given in Table 2. The information given has the average values at national scale. For the inventory analyses district-wise populations of different livestock categories [i.e. males, females (lactating versus non lactating), calves] were considered. Since the different categories of cattle and buffaloes comprise the majority of the livestock in Sri Lanka (Table 1), this study focused mostly on estimating the country-specific $\mathrm{CH}_{4}$ emission factors for the subcategories of these two animal groups. In addition, the emission factors for sheep and goats were estimated considering the populations of the latter two groups together.

Country-specific emission factors were derived using the nationally available breed- and subpopulation information; each animal category was further 
subdivided for the analyses. It was considered that all the cattle in Sri Lanka are used for dairy (not meat) production, and the cattle population was subdivided as mature dairy cows, mature bulls, and growing cattle (i.e. calves, heifers). The average milk production in improved and local cows in different ecological zones (i.e. dry, intermediate, wet hilly, and other wet regions; Table 3) were considered in estimating the final weighted average for each animal subcategory in the country. For estimating the $\mathrm{CH}_{4}$ emission factor from enteric fermentation, a Tier 2 approach was used in gross energy calculations (IPCC, 2006) based on country-specific activity data, including the information provided in Tables 1, 2 and 3.

The estimation of $\mathrm{CH}_{4}$ emission factor for different subcategories of cattle and buffaloes incorporated the calculation of the following energy components using the algorithms detailed in IPCC (2006): maintenance energy $\left(\mathrm{NE}_{\mathrm{m}}\right)$ calculation based on the body weights of different subcategories of the livestock (Table 1); activity energy $\left(\mathrm{NE}_{\mathrm{a}}\right)$ calculation concerning the maintenance energy and the energy expenditure in finding food; growth energy $\left(\mathrm{NE}_{\mathrm{g}}\right)$ for the young considering average daily weight gain and live average- and mature body weights (Table 2); lactation energy $\left(\mathrm{NE}_{1}\right)$ calculation using the milk production and the percentage of milk fat (Tables 2 and 3); work energy $\left(\mathrm{NE}_{\text {work }}\right)$ based on the body weight (Table 2) and the number of hours spent on draft power; pregnancy energy $\left(\mathrm{NE}_{\mathrm{p}}\right)$ as a fraction of the maintenance energy; energy requirement for annual wool production $\left(\mathrm{NE}_{\text {wool }}\right.$; for sheep only); ratios of net energy available in the diet for maintenance and growth with respect to digestible energy consumed (i.e. REM and REG, respectively [(IPCC, 2006); equation (1)]; digestible energy corresponds to the proportion of energy in the feed not excreted in the faeces (IPCC, 2000).

The final gross energy (GE) calculation involved all the above different components of energy and the ratios REM and REG [(IPCC, 2006); equation (1)]. The estimated GE was then used for deriving the final $\mathrm{CH}_{4}$ emission factors for different subcategories of animals [equation (2); (IPCC, 2006)].

$G E=\left[\frac{\left[\frac{\left(N E_{m}+N E_{a}+N E_{l}+N E_{\text {work }}+N E_{p}\right)}{R E M}\right]+\left[\frac{\left(N E_{g}+N E_{\text {wool }}\right)}{R E G}\right]}{\frac{D E \%}{100}}\right]$
Where:

$\mathrm{GE}=$ gross energy for cattle and buffaloes, $\mathrm{MJ}$ day $^{-1}$

$\mathrm{NE}_{\mathrm{m}} \quad=$ net energy required by the animal for maintenance, $\mathrm{MJ}$ day $^{-1}$

$\mathrm{NE}_{\mathrm{a}}=$ net energy for animal activity, $\mathrm{MJ}$ day $^{-1}$

$\mathrm{NE}_{1}=$ net energy for lactation, $\mathrm{MJ}$ day ${ }^{-1}$

$\mathrm{NE}_{\text {work }}=$ net energy for work, $\mathrm{MJ}$ day $^{-1}$

$\mathrm{NE}_{\mathrm{p}}{ }^{\text {work }}=$ net energy required for pregnancy, $\mathrm{MJ}_{\text {day }}{ }^{-1}$

REM = ratio of net energy available in a diet for maintenance to digestible energy consumed

$\mathrm{NE}_{\mathrm{g}} \quad=$ net energy needed for growth, $\mathrm{MJ}$ day $^{-1}$

$\mathrm{NE}_{\text {wool }}$ = net energy required to produce a year of wool, MJ day ${ }^{-1}$ (considered only for sheep)

REG = ratio of net energy available for growth in a diet to digestible energy consumed

$\mathrm{DE} \%=$ digestible energy expressed as a percentage of gross energy

$E F=\left[\frac{\left[G E * \frac{\left(Y_{m}\right)}{100}\right] * 365}{55.65}\right]$

Where:

$\mathrm{EF}=$ emission factor, $\mathrm{kg} \mathrm{CH}_{4}$ head $^{-1} \mathrm{yr}^{-1}$

$\mathrm{GE}=$ gross energy intake, $\mathrm{MJ}^{4}$ head $^{-1}$ day $^{-1}$

$\mathrm{Y}_{\mathrm{m}}=$ methane conversion factor, per cent of gross energy in feed converted to methane

The factor $55.65\left(\mathrm{MJ} / \mathrm{kg} \mathrm{CH}_{4}\right)$ is the energy content of methane.

The above detailed components of gross energy (i.e. maintenance energy, activity energy, lactation energy, growth energy, pregnancy energy, etc.) and $\mathrm{CH}_{4}$ emission factors were estimated for different ruminant livestock categories. All the energy estimates and $\mathrm{CH}_{4}$ emission factors were estimated separately for the improved and local populations of lactating females, non-lactating females, mature bulls, and calves (less than 3 years).

Final $\mathrm{CH}_{4}$ emission factors were estimated for the two main IPCC categories: dairy (i.e. mature cows that are producing milk in commercial quantities for human consumption), and other cattle (i.e. cows not currently lactating, bulls, and calves). The final $\mathrm{CH}_{4}$ emission factor for other cattle was calculated as a population-weighted estimate based on the population of each subcategory involved (Table 5). Forty seven percent of the other cattle in the local population were calves. It was assumed that calves less than 3 months emit a negligible amount of $\mathrm{CH}_{4}$ (and thus avoided in the estimation of $\mathrm{CH}_{4}$ ), and assumed to be $20 \%$ of the total calf population. 
Table 3: $\quad$ Average daily milk production* $\left(\mathrm{kg} \mathrm{head}^{-1} \mathrm{day}^{-1}\right)$

\begin{tabular}{lccc}
\hline Agro-ecological zone & Local cows & Improved cows & Buffaloes \\
\hline Dry & 1.0 & 2.7 & 1.0 \\
Intermediate & 1.0 & 3.0 & 0.7 \\
Wet hilly & 2.0 & 6.0 & 1.1 \\
Low country wet & 1.3 & 3.4 & 0.8 \\
\hline
\end{tabular}

* These estimates were based on the population and milk production data at district level [Source: Census of Agriculture 2002, Department of Census and Statistics (http://www.statistics.gov.lk/agriculture/)]; certain estimates were amended considering the values observed for main dairy production systems within the country (Ibrahim et al., 1999; Bandara, 2001; Ranaweera, 2009)

Due to lack of exact information, several assumptions had to be made in estimating certain energy components using the IPCC (2006) Tier 2 guidelines. In estimating the activity energy, the IPCC (2006) has provided default activity coefficients of 0 and 0.17 (dimensionless) for stall-fed [i.e. confined to small areas (tethered, pen, or barn)] and pasture-fed cattle, respectively; the activity coefficient for pasture fed cattle given by the IPCC (2006) was modified by using multiplication factors of 0.4 and 0.5 for improved and local cattle, respectively, as they are stall-fed (and fodder- and concentrate-fed) during certain periods of their life. In estimating the work energy for mature cattle and buffaloes, the number of work hours per day was assumed as 1.2 hrs per day considering the very low annual use of draft power within the country. The work energy and pregnancy energy coefficients given by the IPCC (2006) for cattle and buffaloes were further modified considering the fraction of draught animals in the population (i.e. 0.6 and 0.8 in improved and local cattle populations, respectively) and the percentage of females giving birth in a year (i.e. 70 and $85 \%$ in improved and local cows, respectively). The average calf weight for each livestock category was estimated based on the birth weights and daily weight gains (Table 2), considering the population of growing animals/calves under 3 years of age. The digestible energy was considered as $70 \%$ and $55 \%$ for improved and indigenous cattle, respectively, based on the expert opinion and the percentages suggested by IPCC (2006); a lower methane conversion factor (i.e. $5.5 \%$ ) was considered for the improved cattle, compared to the local population (i.e. $6.5 \%$ ), based on the value ranges given by IPCC (2006).

The improved buffaloes constituted only $9 \%$ of the total population, and thus weighted emission factors were derived using the Tier 2 method for dairy and other buffaloes considering the percentage of local and improved buffaloes in the total population. Sixty percent digestible energy was assumed for improved buffaloes, while $55 \%$ digestible energy was assumed for local buffaloes based on expert opinion; a methane conversion factor of $6.0 \%$ was considered.

\section{RESULTS AND DISCUSSION}

The estimates of energy components in different livestock categories using IPCC (2006) guidelines involved elaborate calculations; the estimates made for cattle are provided in Table 4 . The methane emission factors estimated by including the energy estimates in equation 1 and equation 2 are given in Table 5 .

Out of all the cattle subcategories, indigenous mature bulls had the highest methane emission factors. Due to occasional use in draft power and high maintenance requirement due to larger size and body weight, indigenous mature bulls had higher $\mathrm{CH}_{4}$ emission factors compared to the cows. The emission factor for the improved dairy cows is slightly lower than that for the improved bulls. Improved bulls weighed between $200-400 \mathrm{~kg}$, requiring more maintenance energy compared to the cows and indigenous bulls. The overall gross energy intake and $\mathrm{CH}_{4}$ emission factors were lower for the cows and bulls of the improved varieties compared to the indigenous ones, due to higher digestible energy associated with the feed given to the improved cattle.

However, the improved calves had higher emission factors compared to the indigenous ones, mostly due to the higher maintenance and growth energy associated with their larger body size and weight. The lactating cows in both indigenous and improved cattle had higher $\mathrm{CH}_{4}$ emission factors compared to the non-lactating cows.

When a population-weighted emission factor was calculated for the dairy cattle in Sri Lanka considering the separate emission factors estimated for the improved and local cattle (Table 5), it yielded a value of $50 \mathrm{~kg}$ $\mathrm{CH}_{4}$ head $^{-1}$, which is lower than the IPCC (2006) default 
Table 4: Estimated values for different energy components in cattle

\begin{tabular}{|c|c|c|c|c|c|c|c|}
\hline \multirow[t]{2}{*}{ Cattle sub category } & \multicolumn{7}{|c|}{ Energy components (MJ day $\left.{ }^{-1}\right)$} \\
\hline & $\mathrm{NE}_{\mathrm{m}}$ & $\mathrm{NE}_{\mathrm{a}}$ & $\mathrm{NE}_{1}$ & $\mathrm{NE}_{\text {work }}$ & $\mathrm{NE}_{\mathrm{p}}$ & $\mathrm{NE}_{\mathrm{g}}$ & GE \\
\hline Lactating cows (improved) & 21.1 & 9 & 13 & na & na & na & 116 \\
\hline Lactating cows (local) & 17.4 & 10 & 4 & na & na & na & 120 \\
\hline Non-lactating cows (improved) & 17.6 & 14.1 & na & na & 2 & na & 90 \\
\hline Non-lactating cows (local) & 14.5 & 13.6 & na & na & 2 & na & 114 \\
\hline Bulls (improved) & 26 & 19.6 & na & 2 & na & na & 128 \\
\hline Bulls (local) & 18.2 & 15.3 & na & 2 & na & na & 136 \\
\hline Calves (improved) & 8 & 9 & na & na & na & 9 & 43 \\
\hline Calves (local) & 6 & 7 & na & na & na & 4 & 25 \\
\hline
\end{tabular}

$\mathrm{NE}_{\mathrm{m}}=$ net energy for maintenance; $\mathrm{NE}_{\mathrm{a}}=$ net energy activity; $\mathrm{NE}_{1}=$ net energy for lactation, $\mathrm{NE}_{\text {work }}=$ net energy for work; $\mathrm{NE}_{\mathrm{p}}=$ net energy for pregnancy, $\mathrm{NE}_{\mathrm{g}}=$ net energy for growth, $\mathrm{GE}$ = gross energy; $\mathrm{REM}$ used in GE calculation for improved and local cattle were 0.53 and 0.47 , respectively; REG for improved and local cattle were 0.33 and 0.247 , respectively; na - not applicable

Table 5: $\quad \mathrm{CH}_{4}$ emission factors estimated for enteric fermentation in Sri Lankan cattle and buffaloes estimated using IPCC (Tier 2) method

\begin{tabular}{|c|c|c|c|}
\hline \multicolumn{2}{|l|}{ Livestock category } & \multicolumn{2}{|c|}{$\mathrm{CH}_{4}$ emission kg head ${ }^{-1} \mathrm{yr}^{-1}$} \\
\hline \multicolumn{2}{|l|}{ Dairy cattle } & $50 *$ & (IPCC default-58) \\
\hline \multicolumn{2}{|l|}{- local } & \multicolumn{2}{|l|}{52} \\
\hline \multicolumn{2}{|c|}{ - improved } & \multicolumn{2}{|l|}{42} \\
\hline \multicolumn{2}{|l|}{ Other cattle } & $32 *$ & (IPCC default-27) \\
\hline \multicolumn{2}{|c|}{ - local } & \multicolumn{2}{|c|}{$32 * *$} \\
\hline \multicolumn{2}{|c|}{ - improved } & \multicolumn{2}{|l|}{$26^{* *}$} \\
\hline \multicolumn{4}{|c|}{ Estimates for sub categories: } \\
\hline \multicolumn{2}{|c|}{ Non-lactating cows- local } & \multicolumn{2}{|l|}{49} \\
\hline \multirow{3}{*}{ Mature bulls } & - improved & \multicolumn{2}{|l|}{32} \\
\hline & - local & \multicolumn{2}{|l|}{58} \\
\hline & - improved & \multicolumn{2}{|l|}{46} \\
\hline \multirow[t]{2}{*}{ Calves } & - local & \multicolumn{2}{|l|}{11} \\
\hline & - improved & \multicolumn{2}{|l|}{16} \\
\hline \multicolumn{2}{|l|}{ Buffaloes } & $49 *$ & (IPCC default-55) \\
\hline \multicolumn{2}{|l|}{ Dairy } & \multicolumn{2}{|l|}{65} \\
\hline Other buffalc & & \multicolumn{2}{|l|}{44} \\
\hline \multicolumn{2}{|l|}{ Sheep } & 3 & (IPCC default-5) \\
\hline
\end{tabular}

\footnotetext{
* Final weighted average, as described within the text

** weighted average based on the populations of sub categories
}

value of $58 \mathrm{~kg} \mathrm{CH}_{4}$ head $^{-1}$ for the Indian subcontinent. The values for the other cattle subcategories ranged from 11 to $58 \mathrm{~kg} \mathrm{CH}_{4}$ head $^{-1}$ (Table 5), yielding a populationweighted value of $32 \mathrm{~kg} \mathrm{CH}_{4}$ head $^{-1}$, which is slightly higher than the default value of $27 \mathrm{~kg} \mathrm{CH}_{4}$ head $^{-1}$ given by the IPCC (2006).
The IPCC default emission factor for other cattle has considered non-lactating cows, bulls, and calves, with calves comprising a larger proportion among the other cattle categories; however, according to the cattle population census in Sri Lanka, the proportion of calves is less than 50 percent of the other cattle category, 
contributing to a slightly higher emission factor for the other cattle. The population-weighted emission factors calculated for buffaloes (i.e. $49 \mathrm{~kg} \mathrm{CH}_{4}$ head $^{-1}$ ) and sheep (i.e. $3 \mathrm{~kg} \mathrm{CH}_{4}$ head $^{-1}$ ) were lower than the IPCC (2006) default values of 55 and $5 \mathrm{~kg} \mathrm{CH}_{4}$ head $^{-1}$, respectively. When the overall methane emissions calculated using the above emission factors from the three different ruminant livestock groups were compared, cattle, buffaloes, and sheep contributed to 72,27 , and $1 \%$ of the total emissions, respectively.

According to the IPCC (1997a; b; c; 2006) guidelines and good practice guidance (IPCC, 2000; 2003), the member countries are encouraged to develop countryspecific emission factors. Therefore, the methane emission factors derived for livestock subcategories in the current study will help improve the emission estimates in the next national greenhouse gas inventory to be produced by the country. However, due to lack of certain specific information required under the IPCC (2006) Tier 2 methodology, a few assumptions had to be made as described above; for instance, since there is no information available within the country on the daily use of draft power from cattle and buffaloes and the fraction of cattle exclusively grazing on pastures, the values had to be determined based on expert opinion. Therefore, the estimates from the current study might involve some uncertainty, although all the population data and majority of the coefficients used were countryspecific. The emission factors estimated in the present study need to be validated in the future, once a countrywide measurement network for methane emissions from livestock is undertaken in Sri Lanka.

\section{CONCLUSION}

The methane emission factors estimated in this study using IPCC (2006) Tier 2 methodology are more representative of the national circumstances, as they are based on country-specific population characteristics. Overall, the estimated emission factors were lower than the default emission factors given by the IPCC (2006) for the Indian sub-continent except for other cattle, which had a slightly higher value. The methane emission factors estimated in this study will be helpful in improving the emission estimates of future national greenhouse gas inventories to be produced by Sri Lanka, and validation of the current estimates through adequate measurements will be worthwhile.

\section{Acknowledgement}

The initial stages of this study were conducted while the author was serving at the Colorado State University, USA, and the funding for data collection within Sri Lanka was provided by the United Nations Development Programme (UNDP) under the TOKTEN (Transfer of Knowledge Through Expatriate Nationals) Programme. The support provided by Dr B.H.W.M.U.S. Bandara, former Director (Planning) of the Ministry of Livestock Development, and the officials of the Climate Change Secretariat of the Ministry of Environment, Sri Lanka is highly appreciated.

\section{REFERENCES}

1. Abeygunawardena H., Rathnayaka D. \& Jayatilake W.M.A.P. (1997). Characteristics of cattle farming systems in Sri Lanka. Journal of the National Science Council of Sri Lanka 25(1): 25 - 38 .

DOI: http://dx.doi.org/10.4038/jnsfsr.v25i1.5016

2. Bandara B.H.W.M.U.S. (2001). The current status of smallholder dairy systems in Sri Lanka. Smallholder dairy production and marketing - opportunities and constraints. Proceedings of a South-South Workshop held at National Dairy Development Board (NDDB) (eds. D. Rangnekar \& W. Thorpe), Anand, India, 13 - 16 March 2001. National Dairy Development Board, India, Australian Centre for International Agricultural Research, Australia, and International Livestock Research Institute, Kenya, pp. 22 - 32.

3. Bandara D.M.D.S., Premaratne S. \& Dematawewa C.M.B. (2011). Production and economic characteristics of intensive and semi-intensive dairy cattle management systems in vegetable based farming system in Welimada, Sri Lanka. Tropical Agricultural Research 22(3): 314 - 323. DOI: http://dx.doi.org/10.4038/tar.v22i3.3704

4. Blaxter K.L. (1967). The Energy Metabolism of Ruminants, pp. 110 - 112. Hutchinson, London, UK.

5. Buvendran V. (1977). Production characteristics of Jersey-Sindhi grades in Sri Lanka. Australian Journal of Agricultural Research 28: 747 - 753.

DOI: http://dx.doi.org/10.1071/AR9770747

6. Central Bank of Sri Lanka (2013). Annual Report 2013. Central Bank of Sri Lanka, Colombo 01.

7. Department of Census and Statistics (2002). Available at http://www.statistics.gov.lk/agriculture/, Accessed 10 July 2015.

8. Ibrahim M.N.M., Staal S.J., Daniel S.L.A. \& Thorpe W. (1999). Appraisal of the Sri Lanka Dairy Sector, volume 1: Synthesis Report. Department of Animal Science, University of Peradeniya, International Livestock Research Institute, Nairobi, Kenya, and Ministry of Livestock Development and Estate Infrastructure, Colombo, Sri Lanka.

9. Intergovernmental Panel on Climate Change (IPCC) (1997a). Revised 1996 IPCC Guidelines for National Greenhouse Gas Inventories: Reporting Instructions (eds. J.T. Houghton, L.G. Meira Filho, B. Lim, K. Tréanton, I. Mamaty., Y. Bonduki, D.J. Griggs \& B.A. Callander), volume 1. IPCC, Meteorological Office, Bracknell, UK. 
10. Intergovernmental Panel on Climate Change (IPCC) (1997b). Revised 1996 IPCC Guidelines for National Greenhouse Gas Inventories: Workbook (eds. J.T. Houghton, L.G. Meira Filho, B. Lim, K. Tréanton, I. Mamaty, Y. Bonduki, D.J. Griggs \& B.A. Callander), volume 2. IPCC, Meteorological Office, Bracknell, UK.

11. Intergovernmental Panel on Climate Change (IPCC) (1997c). Revised 1996 IPCC Guidelines for National Greenhouse Gas Inventories: Reference Manual (eds. J.T. Houghton, L.G. Meira Filho, B. Lim, K. Tréanton, I. Mamaty, Y. Bonduki, D.J. Griggs \& B.A. Callander), volume 3. IPCC, Meteorological Office, Bracknell, UK.

12. Intergovernmental Panel on Climate Change (IPCC) (2000). Good Practice Guidance and Uncertainty Management in National Greenhouse Gas Inventories [eds. J. Penman et al. (12 editors)]. Intergovernmental Panel on Climate Change (IPCC)/Institute for Global Environmental Strategies (IGES), Hayama, Japan.

13. Intergovernmental Panel on Climate Change (IPCC) (2003). Good Practice Guidance for Land Use, Land-Use Change and Forestry [eds. J. Penman et al. (11 editors)]. Intergovernmental Panel on Climate Change (IPCC)/ Institute for Global Environmental Strategies (IGES), Hayama, Japan.

14. Intergovernmental Panel on Climate Change (IPCC) (2006). 2006 IPCC Guidelines for National Greenhouse Gas Inventories, Prepared by the National Greenhouse Gas
Inventories Programme (eds. H.S. Eggleston, L. Buendia, K. Miwa, T. Ngara \& Tanabe K.). Institute for Global Environmental Strategies (IGES), Hayama, Japan.

15. Johnson K.A. \& Johnson D.E. (1995). Methane emissions from cattle. Journal of Animal Science 73: 2483 - 2492.

16. Knapp J.R., Laur G.L., Vadas P.A., Weiss W.P. \& Tricarico J.M. (2014). Invited review: enteric methane in dairy cattle production: quantifying the opportunities and impact of reducing emissions. Journal of Dairy Science 97: 3231 - 3261. DOI: http://dx.doi.org/10.3168/jds.2013-7234

17. Ranaweera N.F.C. (2009). Sri Lanka: opportunities for dairy sector growth. Smallholder Dairy Development: Lessons Learned in Asia (ed. N. Morgan), pp. 93 - 105. Animal Production and Health Commission for Asia and the Pacific, Food and Agriculture Organization of the United Nations Regional Office for Asia and the Pacific, Bangkok, Thailand.

18. United Nations Framework Convention on Climate Change (UNFCCC) (2003). UNFCCC documents. FCCC/ CP/2002/7/Add.2. UNFCCC Secretariat, Bonn, Germany. Available at http://unfccc.int/resource/docs/cop8/07a02. pdf, Accessed 3 July 2015.

19. Zemmelink G., Premaratne S., Ibrahim M.N.M. \& Leegwater P.H. (1999). Feeding of dairy cattle in the forest-garden farms of Kandy, Sri Lanka. Tropical Animal Health and Production 31: 307 - 319.

DOI: http://dx.doi.org/10.1023/A:1005255823706 